\title{
Particularities Regarding the Wear of SPMR150612-P30 Metallic Carbide Inserts
}

\author{
Raluca DAICU \\ Transilvania University of Brașov, Romania, raluca.daicu@unitbv.ro \\ Valentin DIȚU \\ Transilvania University of Brașov, Romania, vditu@unitbv.ro
}

\begin{abstract}
Metal cutting processes still present a high weight in obtaining various parts needed for the industry, both due to the quality of the surfaces and especially to the dimensional and geometric precision. The cutting tools are in continuous development and their wear is a constant concern of the researchers. Standardization of wear forms has become a necessity and ISO 3685/1993 is an example in this regard. However, the measurement of the average wear on the cutting tool flank is not detailed in the standard. This question naturally arises "In how many points should wear be measured on flank so that the average values are as close to reality as possible?". If in the case of a uniform wear the approach is simple, not the same thing happens when the wear is non-uniform. This paper analyzes in detail a non-uniform wear on the flank of a metal carbide plate mechanically fixed and through experiments proposes the optimum interval of making the measurements so that the average of values is as close to the average of the finer used interval, in this way significantly reducing the time spent on measurements.
\end{abstract}

\section{Keywords}

cutting, turning, wear of cutting tool

\section{Introduction}

The obtaining of the metal parts by cutting is, for the moment, the modality with the highest weight in all the mechanical processes. A significant number of specialty papers have dealt with the cutting process in order to understand the relations and phenomena that occur when the cutting layer crosses into the chip $[1,2,3,4]$ in order to find ways to increase the quality of the processed surfaces but especially the dimensional and geometric precision. The paper [3] logically summarizes the phenomena that occur in the cutting process and groups them into primary actions that cause effects (Figure 1).

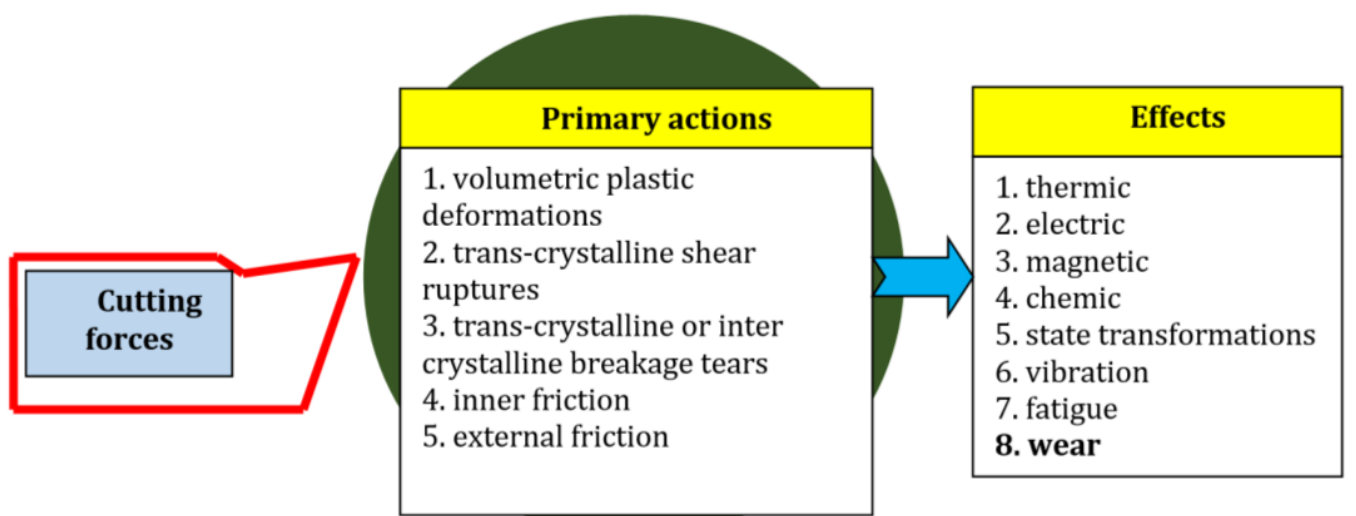

Fig. 1. Identification of primary actions and effects during cutting, according to [3]

The effect with the most important consequences is that of wear because it causes the decrease of cutting tool life. Also in the work [3] it is shown that the cutting process is a primary system with a degenerative loop where the wear is both an element of entry and an element of exit from the system.

Some effects, such as the electric one, that appears during metal cutting processes with good 
electricity conductor cutting edges, reports the quality of the cutting edge (according to [5]). The bibliographic sources $[3,4]$ show that when cutting the same material under the same conditions, the electric cutting current is also depending on the wear of the cutting edge.

The importance of the permanent study of the cutting tool wear is also highlighted in papers $[6,7,8]$.

Figure 2 shows the wear characteristics of the cutting edge on the flank of the cutting tool, according to ISO 3685/1997. The flank wear presents the highest interest because it appears on any type of cutting edge and represents the criterion used in determining the tool's life.

As presented in Figure 2, according to ISO 3685, the worn part of the cutting edge is divided into three main areas:

- area $\mathrm{C}$ - the corner wear;

- area B - the flank wear;

- area $\mathrm{N}$ - the notch wear.

The cutting tool life is determined by the two main wear parameters measured in B area:

- VBMAX - the maximum wear;

- VBB - the average wear.

The source [2] recommends the next values $\mathrm{VBB}=0.3 \mathrm{~mm}$ and $\mathrm{VBMAX}=0.6 \mathrm{~mm}$.

When the maximum wear does not exceed $30 \%$ of the average wear it is included in the average wear. When cutting certain materials, it may or may not appear, together with the flank wear, the crater wear on the rake surface. In Figure 3 is presented the crater wear, according to ISO 3695/1993, where:

- KT - crater depth;

- KM - distance between the cutting edge and the deepest crater point;

- KB - distance between the cutting edge and the back crater contour;

- KF - width of the land between the crater and the cutting edge;

- KE - radial displacement of the tool corner.

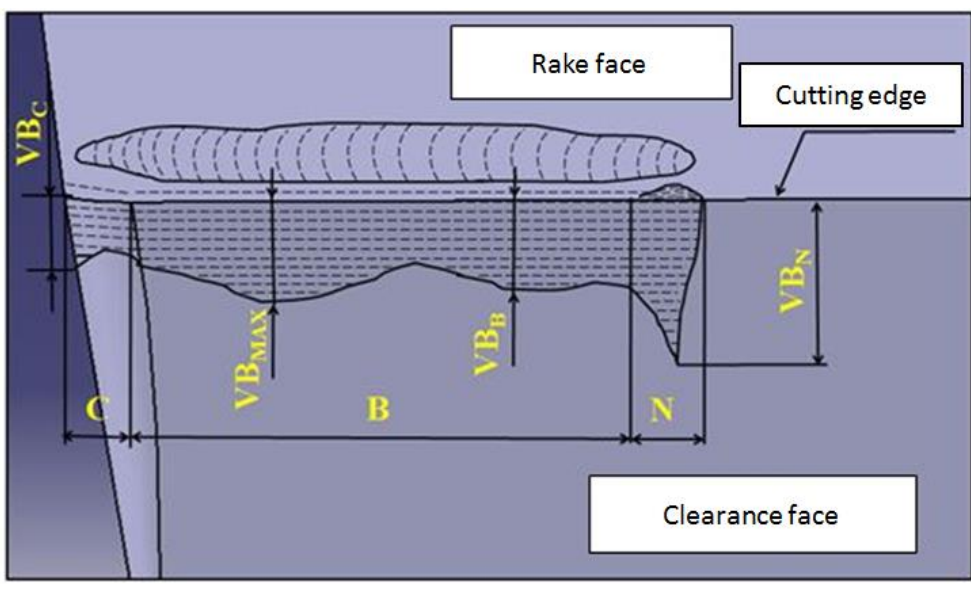

Fig. 2. Flank wear characteristics, according to ISO $3685 / 1993$

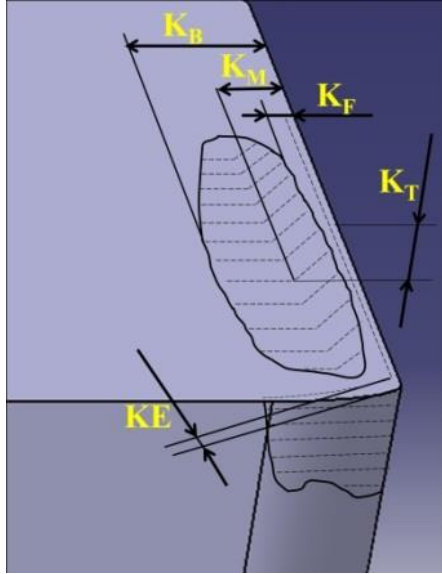

Fig. 3. Crater wear characteristics, according to ISO 3685/1993

The main causes of wear appearance, according to $[1,2,3,4]$ are:

- abrasive wear;

- adhesive wear;

- diffusion wear;

- oxidation wear (chemical wear);

- wear due to electrical current at cutting;

- fatigue wear (thermal stresses and / or pulsating stresses - determines the chipping of the cutting edge).

Details of the causes are also shown in the bibliographic sources mentioned above.

The ones mentioned above highlight the importance of measuring the average wear on the clearance face of the cutting tool. 


\section{Experimental Determination of the Wear Measurement Increment on the Clearance Face}

In order to determine the optimum incremental step of measuring the wear on the clearance face of the cutting tool for the calculation of the average wear, a batch of six inserts of metallic carbide type SPMR150612-P30 was chosen, and the 1C45 steel was turned. The used tool holder determinate the next geometry: $\alpha=50 ; \gamma=60 ; \chi=45^{0}$. No cutting fluid was used and it was cut to a wear on the clearance face of $0.6 \div 0.7 \mathrm{~mm}$.

The used cutting parameters for turning is shown in Table 1 .

Table 1. Cutting parameters used for turning

\begin{tabular}{|c|c|c|c|c|c|c|}
\hline $\begin{array}{c}\text { Cutting parameters } \\
\text { - no cutting fluids - }\end{array}$ & $\begin{array}{c}\text { Carbide } \\
\text { insert 1 }\end{array}$ & $\begin{array}{c}\text { Carbide } \\
\text { insert 2 }\end{array}$ & $\begin{array}{c}\text { Carbide } \\
\text { insert 3 }\end{array}$ & $\begin{array}{c}\text { Carbide } \\
\text { insert 4 }\end{array}$ & $\begin{array}{c}\text { Carbide } \\
\text { insert 5 }\end{array}$ & $\begin{array}{c}\text { Carbide } \\
\text { insert 6 }\end{array}$ \\
\hline Cutting speed [m/min] & 106.03 & 106.03 & 106.03 & 106.03 & 106.03 & 106.03 \\
\hline Cutting feed [mm/rot] & 0.208 & 0.208 & 0.208 & 0.208 & 0.208 & 0.208 \\
\hline Cutting depth [mm] & 2.5 & 2.5 & 4 & 2.5 & 2 & 2.5 \\
\hline
\end{tabular}

The shape of the wear of six edges from six cutting plates, as well as a first measurement of them to stop the cutting process at a wear on the clearance face of $0.6 \div 0.7 \mathrm{~mm}$, in order to choose the representative wear for detailed measurements, was done with using the Mitutoyo microscope shown in Figure 4, with an accuracy of $1 \mu \mathrm{m}$. The six shapes of wear are presented in Figures $5 \ldots 10$.

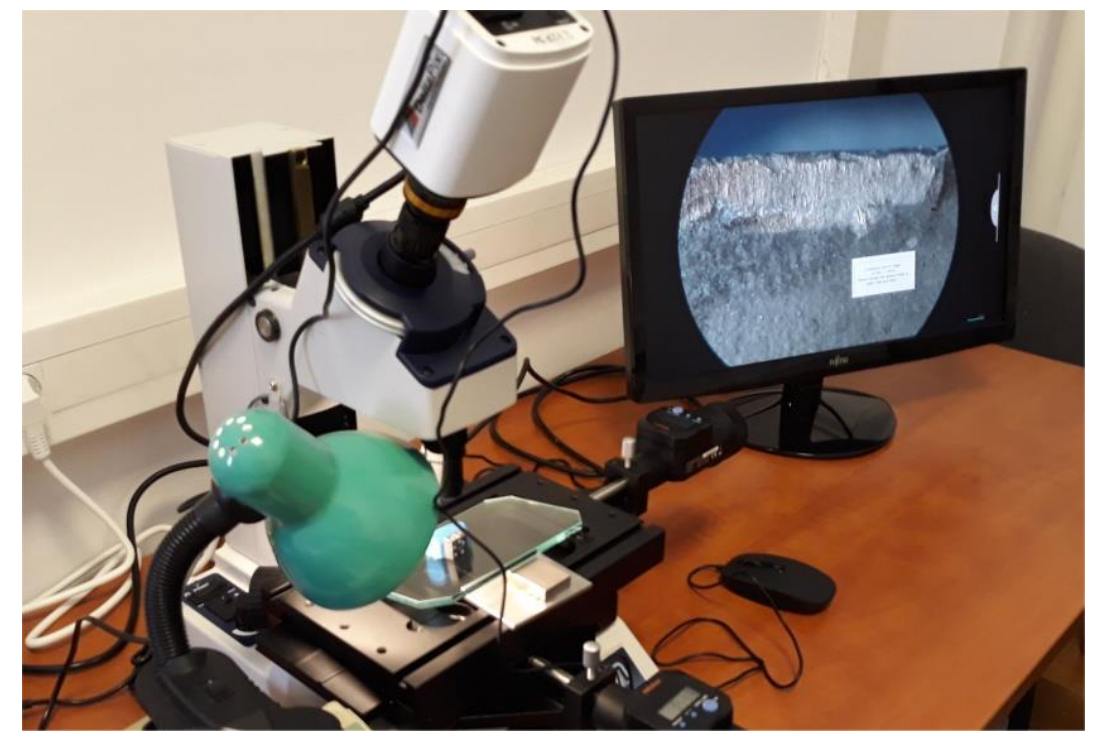

Fig. 4. Microscope for measuring the cutting tool wear

From the figures presented, it can be seen that the wear of the inserts 3, 4, 5 and 6 is uniform and the inserts 1 and 2 have non-uniform wear but the maximum wear is up to $30 \%$ higher than the average wear, which means that it can be assimilated into the average wear. To continue the measurements, the wear of the insert 1 was chosen because it has the highest degree of non-uniformity and at the same time it is noted the chipping of the cutting edge. In Figure 4 it can be observed the wear on the clearance face of cutting insert 1, which is presented also in Figure 5, more detailed. The measurements done with the increment of $0.025 \mathrm{~mm}, 0.05 \mathrm{~mm}, 0.075 \mathrm{~mm}, 0.1 \mathrm{~mm}, 0.125 \mathrm{~mm}, 0.15 \mathrm{~mm}, 0.175 \mathrm{~mm}, 0.2 \mathrm{~mm}, 0.25$ $\mathrm{mm}, 0.3 \mathrm{~mm}, 0.4 \mathrm{~mm}$ and $0.5 \mathrm{~mm}$, for insert 1 , are centralized in Table 2 .

Data from Table 2 are graphically represented in Figure 11.

It is noted that the measurements made with a increment of $0.1 \mathrm{~mm}$ best approximate the measurements made with a increment of $0.025 \mathrm{~mm}$. In this way, instead of 109 measurements, only 28 measurements can be made and the percentage at the average value is $99.44 \%$ from the average value of the measurements made with the increment of $0.025 \mathrm{~mm}$, which is acceptable. 


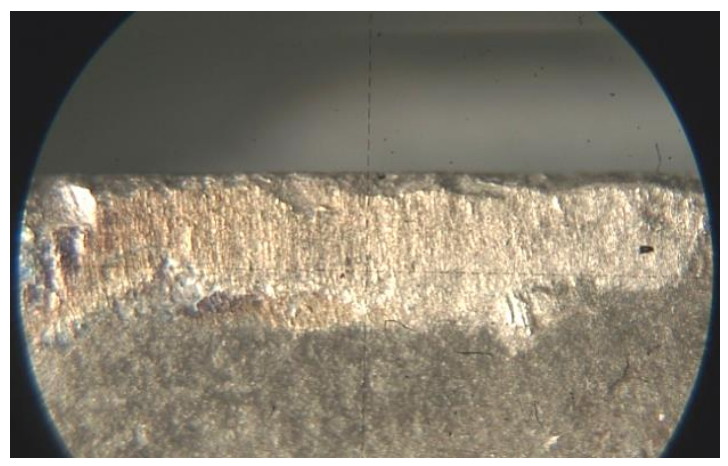

Fig. 5. Wear of insert 1

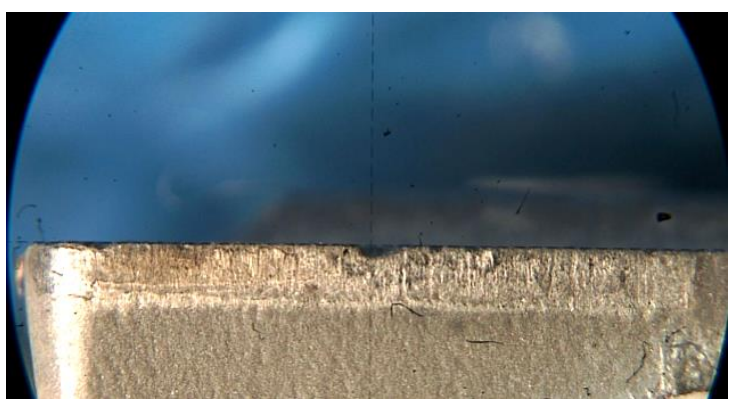

Fig. 7. Wear of insert 3

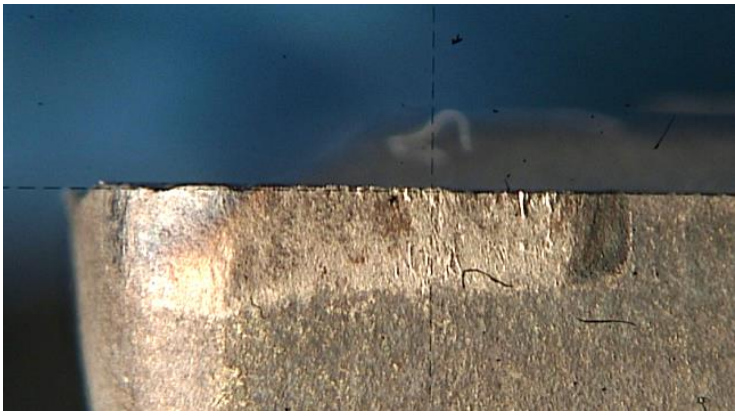

Fig. 9. Wear of insert 5

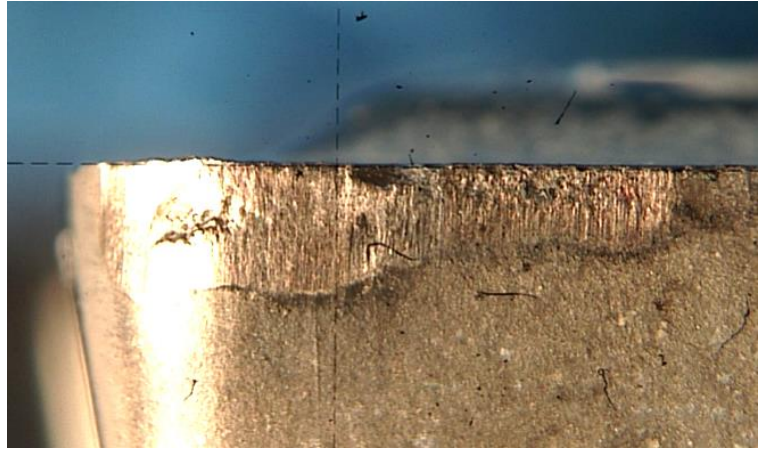

Fig. 6. Wear of insert 2

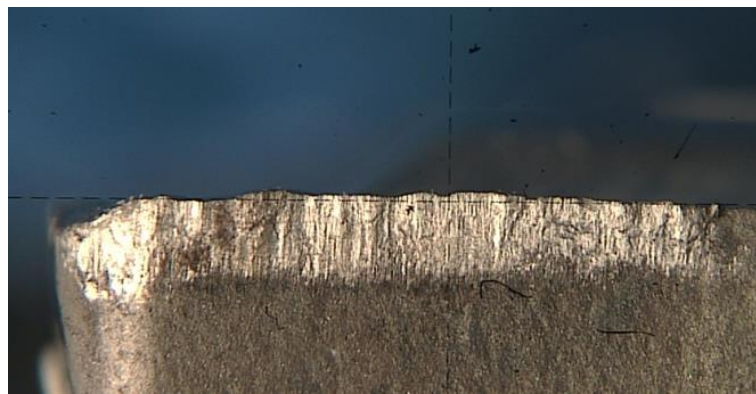

Fig. 8. Wear of insert 4

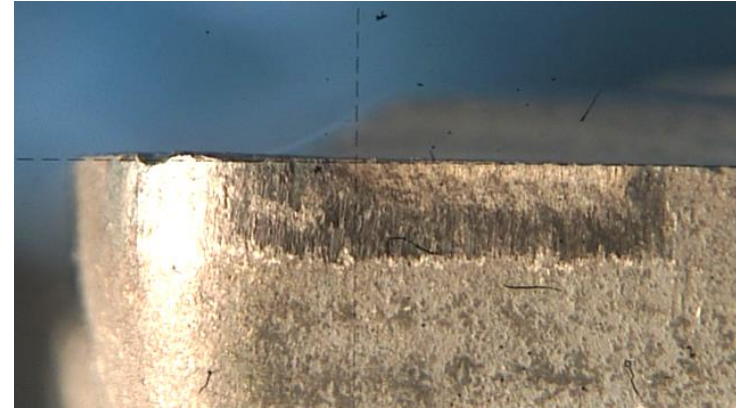

Fig. 10. Wear of insert 6

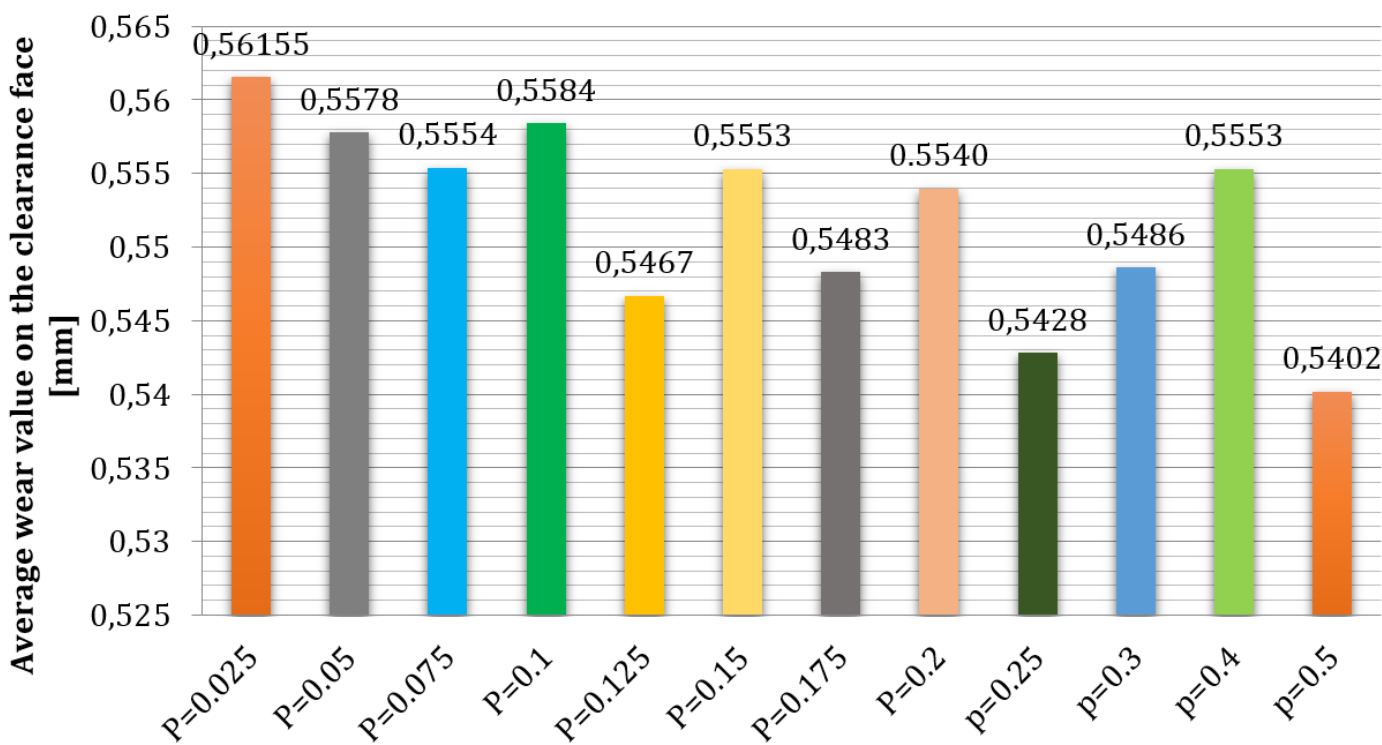

Fig. 11. The graphical representation of the wear average values on the clearance face depending on the increment 
Table 2. Measured wear values for cutting insert 1

\begin{tabular}{|c|c|c|c|c|}
\hline No. & $\begin{array}{l}\text { Increment } \\
\text { step } \\
{[\mathrm{mm}]}\end{array}$ & Wear values [mm] & $\begin{array}{l}\text { Average } \\
\text { wear } \\
\text { "VBB" } \\
{[\mathrm{mm}]}\end{array}$ & $\begin{array}{l}\text { Percentage of } \\
\text { average wear } \\
\text { to } \mathrm{p}=0.025 \\
\mathrm{~mm}[\%]\end{array}$ \\
\hline 1 & 0.025 & $\begin{array}{lllllll}0.372, & 0.378, & 0.434, & 0.432, & 0.450, & 0.431, & 0.441, \\
0.446, & 0.459, & 0.447, & 0.462, & 0.468, & 0.472, & 0.459, \\
0.464, & 0.456, & 0.458, & 0.459, & 0.480, & 0.486, & 0.483, \\
0.516, & 0.535, & 0.553, & 0.559, & 0.587, & 0.615, & 0.638, \\
0.652, & 0.676, & 0.684, & 0.692, & 0.686, & 0.642, & 0.631, \\
0.585, & 0.595, & 0.615, & 0.610, & 0.595, & 0.596, & 0.577, \\
0.591, & 0.598, & 0.608, & 0.606, & 0.613, & 0.618, & 0.624, \\
0.594, & 0.582, & 0.594, & 0.599, & 0.579, & 0.584, & 0.582, \\
0.598, & 0.579, & 0.591, & 0.603, & 0.604, & 0.587, & 0.591, \\
0.614, & 0.619, & 0.594, & 0.590, & 0.592, & 0.593, & 0.560 \\
0.533, & 0.561, & 0.563, & 0.562, & 0.566, & 0.565, & 0.570, \\
0.572, & 0.567, & 0.540, & 0.543, & 0.519, & 0.504, & 0.460 \\
0.458, & 0.441, & 0.436, & 0.433, & 0.451, & 0.463, & 0.469, \\
0.497, & 0.499, & 0.523, & 0.551, & 0.569, & 0.585, & 0.611 \\
0.621, & 0.639, & 0.643, & 0.662, & 0.658, & 0.650, & 0.643, \\
0.640,0.639,0.652,0.654 & & \end{array}$ & 0.56155 & 100 \\
\hline 2 & 0.05 & $\begin{array}{lllllll}0.372, & 0.434, & 0.450, & 0.441, & 0.459, & 0.462, & 0.472, \\
0.464, & 0.458, & 0.480, & 0.483, & 0.535, & 0.559, & 0.615, \\
0.652, & 0.684, & 0.686, & 0.631, & 0.595, & 0.610, & 0.596, \\
0.591, & 0.608, & 0.613, & 0.624, & 0.582, & 0.599, & 0.584, \\
0.598, & 0.591, & 0.604, & 0.591, & 0.619, & 0.590, & 0.593, \\
0.533, & 0.563, & 0.566, & 0.570, & 0.567, & 0.543, & 0.504, \\
0.458, & 0.436, & 0.451, & 0.469, & 0.499, & 0.551, & 0.585 \text {, } \\
0.621,0.643,0.639,0.654 & & & \end{array}$ & 0.5578 & 99.33 \\
\hline 3 & 0.075 & $\begin{array}{lllllll}0.372, & 0.432, & 0.441, & 0.447, & 0.472, & 0.456, & 0.480 \\
0.516, & 0.559, & 0.638, & 0.684, & 0.642, & 0.595, & 0.595 \text {, } \\
0.591, & 0.606, & 0.624, & 0.594, & 0.584, & 0.579, & 0.604 \\
0.614, & 0.590, & 0.560, & 0.563, & 0.565, & 0.567, & 0.519, \\
0.458, & 0.433, & 0.469, & 0.523, & 0.585, & 0.639, & 0.658, \\
0.640, & 0.654 & & & & \end{array}$ & 0.5554 & 98.90 \\
\hline 4 & 0.1 & 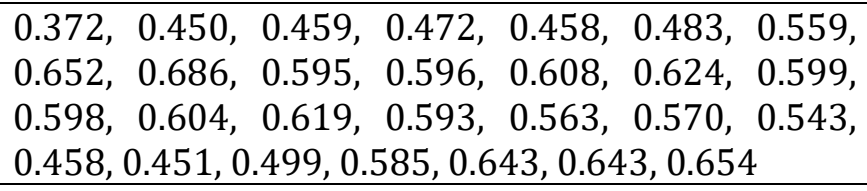 & 0.5584 & 99.44 \\
\hline 5 & 0.125 & 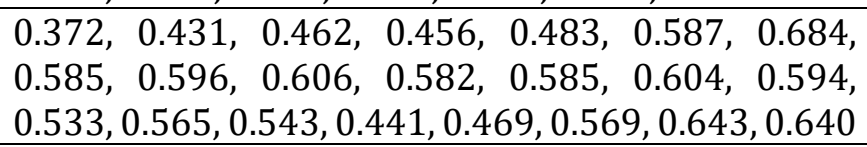 & 0.5467 & 97.36 \\
\hline 6 & 0.15 & 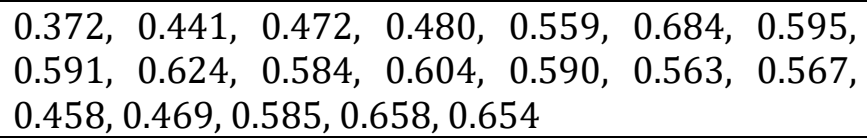 & 0.5553 & 98.89 \\
\hline 7 & 0.175 & $\begin{array}{lllllll}0.372, & 0.466, & 0.464, & 0.516, & 0.652, & 0.585, & 0.591 \text {, } \\
0.594, & 0.598, & 0.614, & 0.533, & 0.572, & 0.458, & 0.497, \\
0.621, & 0.640 & & & & & \\
\end{array}$ & 0.5483 & 97.64 \\
\hline 8 & 0.2 & $\begin{array}{l}0.372,0.459,0.458,0.559,0.686,0.596,0.624 \text {, } \\
0.598,0.619,0.563,0.543,0.451,0.585,0.643\end{array}$ & 0.5540 & 98.66 \\
\hline 9 & 0.25 & $\begin{array}{l}0.372,0.462,0.483,0.684,0.596,0.582,0.604 \text {, } \\
0.533,0.543,0.469,0.643\end{array}$ & 0.5428 & 96.66 \\
\hline
\end{tabular}


RECENT, Vol. 20, no. 3(59), 2019

\begin{tabular}{|l|l|l|l|l|}
\hline 10 & 0.3 & $\begin{array}{l}0.372,0.472,0.559,0.595,0.624,0.604,0.563, \\
0.458,0.585,0.654\end{array}$ & 0.5486 & 97.69 \\
\hline 11 & 0.4 & $0.372,0.458,0.686,0.624,0.619,0.543,0.585$ & 0.5553 & 98.89 \\
\hline 12 & 0.5 & $0.372,0.483,0.596,0.604,0.543,0.643$ & 0.5402 & 96.20 \\
\hline
\end{tabular}

\section{Conclusions}

Due to the measurements and experimental tries, the next conclusions can be drawn:

- the average wear together with the maximum wear on the clearance face of the cutting tool represents the main element for appreciation of the tools life and its most accurate measurement is a necessity;

- when turning 1C45 steel with six SPMR150612-P30 metal carbide cutting inserts, in four of them the wear on the clearance face was uniform and in two it was non-uniform but the maximum wear was higher up to $30 \%$ which allowed its inclusion in medium wear;

- the measurement of the wear with the increments in the range $0.025 \div 0.5 \mathrm{~mm}$ and the graphical representation of the values led to the conclusion that the measurements made with a increment of $0.1 \mathrm{~mm}$ give an error of only $0.56 \%$ compared to the measurements made with the increment of $0.025 \mathrm{~mm}$, which is acceptable because the number of experiments is reduced by $74 \%$;

- finally it is proposed that always, for the research of wear, its measurement should be made with a increment of $0.1 \mathrm{~mm}$.

\section{References}

1. Ștețiu Gr., Lăzărescu I., Oprean C., Ștețiu M. (1994): Teoria și practica sculelor așchietoare (Theory and practice of cutting tools). Vol. I, Editura Universității din Sibiu, ISBN 973-95604-3-1, Sibiu, Romania (in Romanian)

2. Cordebois J.-P., et al. (2003): Fabrication par usinage (Machining manufacturing). Dunod, ISBN 978-2-10005586-9, Paris, France (in French)

3. Dițu V. (2008): Bazele așchierii metalelor. Teorie și aplicații (Fundamentals of cutting metals. Theory and applications). MatrixRom, ISBN 978-973-755-444-4, București, Romania (in Romanian)

4. Fetecău C. (2001): Relații parametrice utilizate la așchiere (Parametric relations when cutting). Editura Tehnică, ISBN 973-31-2020-0, București, Romania (in Romanian)

5. Daicu R., Diţu V., Oancea Gh. (2017): A case study about acquisition of mechanically fixed cutting inserts. MATEC Web of Conferences 137, 03004 (MTeM 2017 - AMaTUC), https://doi.org/10.1051/matecconf/201713703004

6. Diţu V., Muntean C.M. (1998): New Practical Relations Conseming the Wear Determinations and Optimal Cutting to Metal Carbide Plates SPMR 150612-P30 in Turning the OLC45 Steel. Buletinul Institutului Politehnic din Iași, ISSN 1011-2855, Tomul XLIV (VLVIII), Supliment I, Secţia V, Construcţia de Maşini, p. 287-290

7. Capasso S., Paiva J.M. et al. (2019): A novel method of assessing and predicting coated cutting tool wear during Inconel DA 718 turning. Wear, ISSN 0043-1648, Vol. 432-433, https://doi.org/10.1016/j.wear.2019.202949

8. Maruda W.R., Krolczyk G.M. et al. (2017): Tool wear characterizations in finish turning of AISI 1045 carbon steel for MQCL conditions. Wear, ISSN 0043-1648, Vol. 372-373, https://doi.org/10.1016/j.wear.2016.12.006 